\title{
DETERMINANTS OF BEHAVIOR INTENTION AND USE BEHAVIOR AMONG BUKALAPAK'S CONSUMERS
}

\author{
Oxsy Giandi ${ }^{1}$ | Isa Irawan*2 | Rita Ambarwati ${ }^{3}$
}

\footnotetext{
${ }^{1}$ Department of Management of Technology, Institut Teknologi Sepuluh Nopember, Surabaya, Indonesia

${ }^{2}$ Department of Mathematics, Institut Teknologi Sepuluh Nopember, Surabaya, Indonesia

${ }^{3}$ Department of Management, Universitas Muhammadiyah Sidoarjo, Sidoarjo, Indonesia
}

\section{Correspondence}

*Isa Irawan, Department of Mathematics, Institut Teknologi Sepuluh Nopember, Surabaya, Indonesia. Email: mii@its.ac.id

\section{Present Address}

Gedung MMT ITS, Jl. Cokroaminoto 12A, Surabaya 60264, Indonesia

\begin{abstract}
The development of communication and information technology has touched the marketing and sales industry. In recent years, there have been many market places in Indonesia, where people buy and sell without meeting face to face. This study investigates the influence of people's intention on the use of behavior to buy at the market place in Indonesia. The market, which becomes the research object is Bukapalak. The data were obtained using the questionnaire. This study obtained 210 respondents, and the data were processed by the method of partial least square. There is a positive and significant influence of behavioral intention from Bukalapak's consumer on the use (usage) behavior. The dominant determinant indicator in this study is the degree of the purpose of using the market place.
\end{abstract}

\section{KEYWORDS:}

Behavioral Intention, Bukalapak, Market Place, Partial Least Square, Use Behavior

\section{1 | INTRODUCTION}

This part discussed the background of this research, previous research, and research purpose. In Industry 4.0, the integration of communication technology and information from technical processes to business processes in the industry is one of the main ideas in Industry 4.0 ${ }^{11}$. One of the improvements in the use of technology is the rapid development of a product or brand ${ }^{[2]}$. Electronic commerce is the application of technology in the business process ${ }^{3}$. In e-commerce, the place where sellers and buyers meet and make a transaction is called Electronic Market Place (EMs) or better known as the market place ${ }^{4[5]}[14,15]$.

Increasing product sales can depend heavily on the way the product owner markets his product. Increasing the sales number of the product marketing process can use social media ${ }^{6}$. Consumers can freely choose the desired product with the many variations offered. Andreasen $[7$ proposes branding on a product brand must know its brand or competitor's product and the community who will become consumers. One strategy in product branding is product design. The design of a product can be used to attract consumers and change consumer behavior ${ }^{[8}$. 
The design of a product also has a direct impact on the environment. Therefore, before the product is launched into the market, it is first made a product prototype to be tested on consumers. Turhan and Ozbek 9 investigated the influence of a store brand on consumer behavioral intentions in Turkey's clothing store. The analysis results indicate that when the product purchased exceeds the buyer's expectations; the consumer will return to the store. The approach using gender moderators showed slightly different results in two other store brands. Convenience and payment systems influence female consumers more in determining where they buy products than male consumers. When choosing a place to shop, male consumers are more influenced by service when selecting items to buy.

The electronic market currently rivals traditional markets (each producer has a physical store to market products made) with many products sold on social media and market place. At present, well-known brands in the world already have e-commerce markets and work with marketplaces to increase product sales ${ }^{10}$. At the market place, consumers can only see a product's images without being able to touch it. This affects the level of sales and consumer loyalty, especially if the product purchased is not satisfying the consumers 11$]$.

The influence of consumer behavior intentions can be used for strategies in marketing products at a market place. The study results by Zarantonello and Schimtt ${ }^{[12]}$ show that consumers are divided into three, namely holistic consumers, practical consumers, and hedonic consumers. Holistic consumers are most affected by their experience when choosing, buying, and using a product, the utilitarian consumers instead. Hedonic consumers are those who focus on self's satisfaction and are not affected by the product. These three types of consumers influence the level of satisfaction and loyalty on brands and products marketed and sold. Dennis et al. ${ }^{[13]}$ developed a model to analyze the factors that influence e-consumers in purchasing e-shopping. The results of these studies indicate that the intensity of electronic consumers makes purchases based on attitude and trust. The research by Lin and Wang ${ }^{[4]}$ found that the intention of mobile commerce's consumers in Taiwan was strongly influenced by the perceived credibility and perceived financial resources.

This study explains the effect of market place consumer behavior intentions on the use of consumer's preferences in buying products at a market place. Learn investigated mobile banking intention in Taiwan [5]. The investigation's result needed to add the additional variables to predict the usage intention. This study will explain the effect of behavior intention on user behavior. Consumer behavior was investigated to determine the public interest in shopping at the market place in the era of Industry 4.0 in Indonesia. Consumer to consumer $(\mathrm{C} 2 \mathrm{C})$ is a model of e-commerce that describes the sale and purchase transaction between two consumers (individuals) ${ }^{[14}$. One individual as a seller and the other as a buyer.

Rao's investigation study found that perceived risks (join with EM) and expected benefits strongly influenced EM usage ${ }^{[16]}$. The comparison of two models between the Theory of Reasoned Action (TRA) and Theory of Planned Behavior (TPB) provided TRA just identified the opinion ${ }^{[17]}$. Still, TPB could explain detailed information about user intention. TRA and TPB deployed attitude and subject norm. Attitude describes how people feel a behavior, and the subject norm explains the perception of users and their groups. TPB had the third variable, which controlled the individual's belief. TPB better than TRA when investigated behavioral intention. Both of the research's results did not measure the effect between behavioral intention and usage (use behavior). This study ensures the effect of behavioral intention and uses behavior.

Mustaqim investigated the factors which influenced the behavioral intention of an e-commerce customer ${ }^{[18}$. Mustaqim's research used Unified Theory Acceptance and Use Of Technology or UTAUT. UTAUT is one of user acceptance technology framework which measures the factors user acceptance ${ }^{19}$. It combined several user acceptance models. The model in this study is formed based on UTAUT. The investigation related to use (usage) behavior is substantial measurement. The previous behavior or experience impacted the consumer's perception and behavior in the future [20].

In this study, we used a market place with core business consumers to consumers and used Bukalapak consumers as research subjects. The study used a questionnaire method with a random selection of consumers. Questionnaires are made using Google Form and distributed in March to April 2019.

\section{2 | MATERIAL AND METHOD}

This research used two variables from UTAUT-2. There were behavioral intention and use behavior ${ }^{[19}$. The behavioral intention was defined as the degree to which a person formulated conscious plans to perform or not perform some specified future 


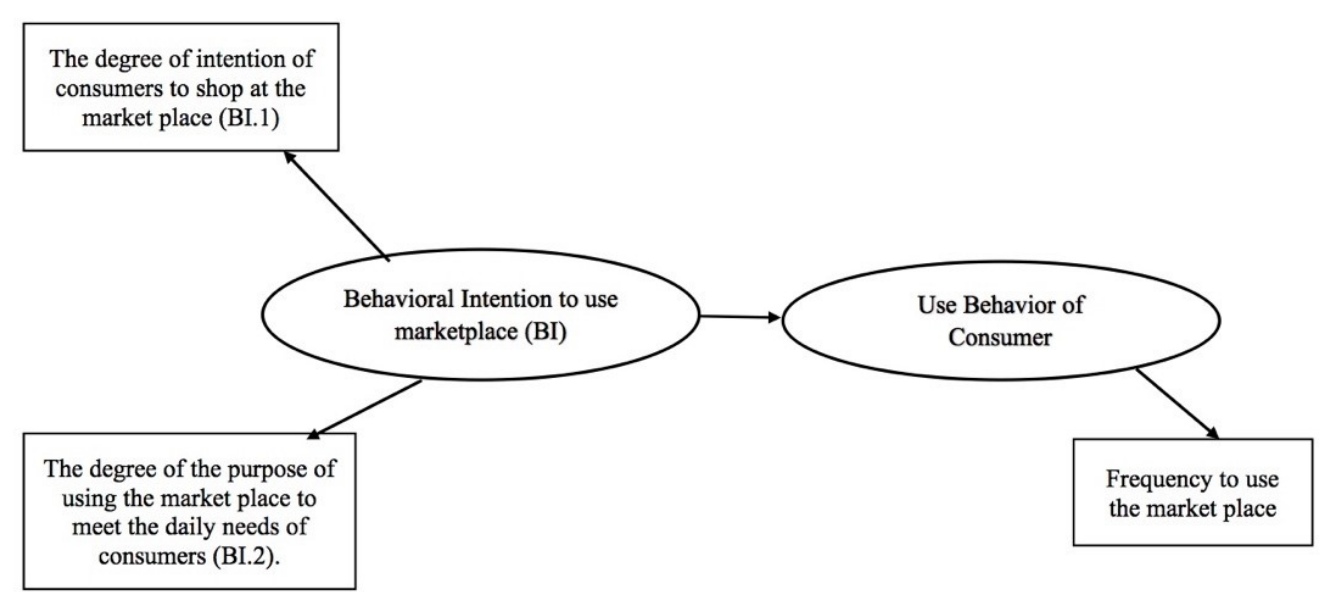

FIGURE 1 The research model.

TABLE 1 Variable operational.

\begin{tabular}{lll}
\hline Research Variables & Indicators & Research Items \\
\hline Behavioral Intention (BI) & Intention (BI.1) & Intention to shop at the market place \\
Use Behavior (UB) & The purpose of using (BI.2) & Use market place to fulfill daily needs \\
& Shopping frequency (UB.1) & To Shop more than five times a month \\
\hline
\end{tabular}

behavior ${ }^{21]}$. Venkatesh formed the indicators of behavioral intention from three items. There are 1) intend to use the system in the next; 2) predict to use the system in the next; 3) plan to use the system in the next.

In this research, the behavioral intention had two research indicators: the measurement of the degree of consumers' intention to shop at the market place (BI.1) and the degree of the purpose of using the market place to meet the daily needs of consumers (BI.2). Predict to use and plan to use on Venkatesh's indicator is combined to become indicators and is named purpose to use. Use (usage) behavior is an action to use technology ${ }^{[22]}$. It can be formed by the frequency to use the technology. In this research, use (usage) behavior is measured by frequency to use the market place.

Figure 1 above is the Behavioral intention as an independent variable. Use behavior is called the dependent variable because the value depends on behavioral intention's measurement. The indicators used in this research are reflective indicators noted with an arrow going out from the latten variable. Reflective indicators are defined as an indicator which becomes a causal indicator on a latten variable. It means that delete one indicator on a latten variable will not change the variable definition. Table 1 shows

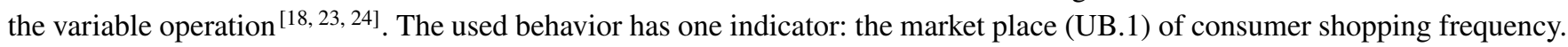
Figure 1, BI.1, BI2, and UB.1 each show research indicators for intention to use, shopping destination, and shopping frequency. The research indicators BI.1 and BI.2 are measured using a Likert scale (1 to 5) where $1=$ strongly disagree, $2=$ disagree, $3=$ neutral, $4=$ agree, $5=$ strongly agree. On UB.1 research indicators, researchers used four scales to map the frequency of market place usage, namely 1 to 2 times a month, 3 to 5 times a month, 4-6 times a month, and seven times a month. The hypothesis of this research is formulated following as:

H0 Behavioral intention has a significant value in influencing consumer behavior in using the market place.

H1 Behavioral intention does not have a significant value in influencing the use of consumer behavior in using the market place.

In this study, the researchers used a simple random sampling method to get respondents. Simple random sampling is a technique of taking samples from a population without specific rules or sampling ${ }^{25]}$. This technique is quite effective for sampling large populations and the exact unknown population. The sample target to be collected in this study comes from people in Indonesia who have smartphones that have already installed the Bukalapak market place application. 


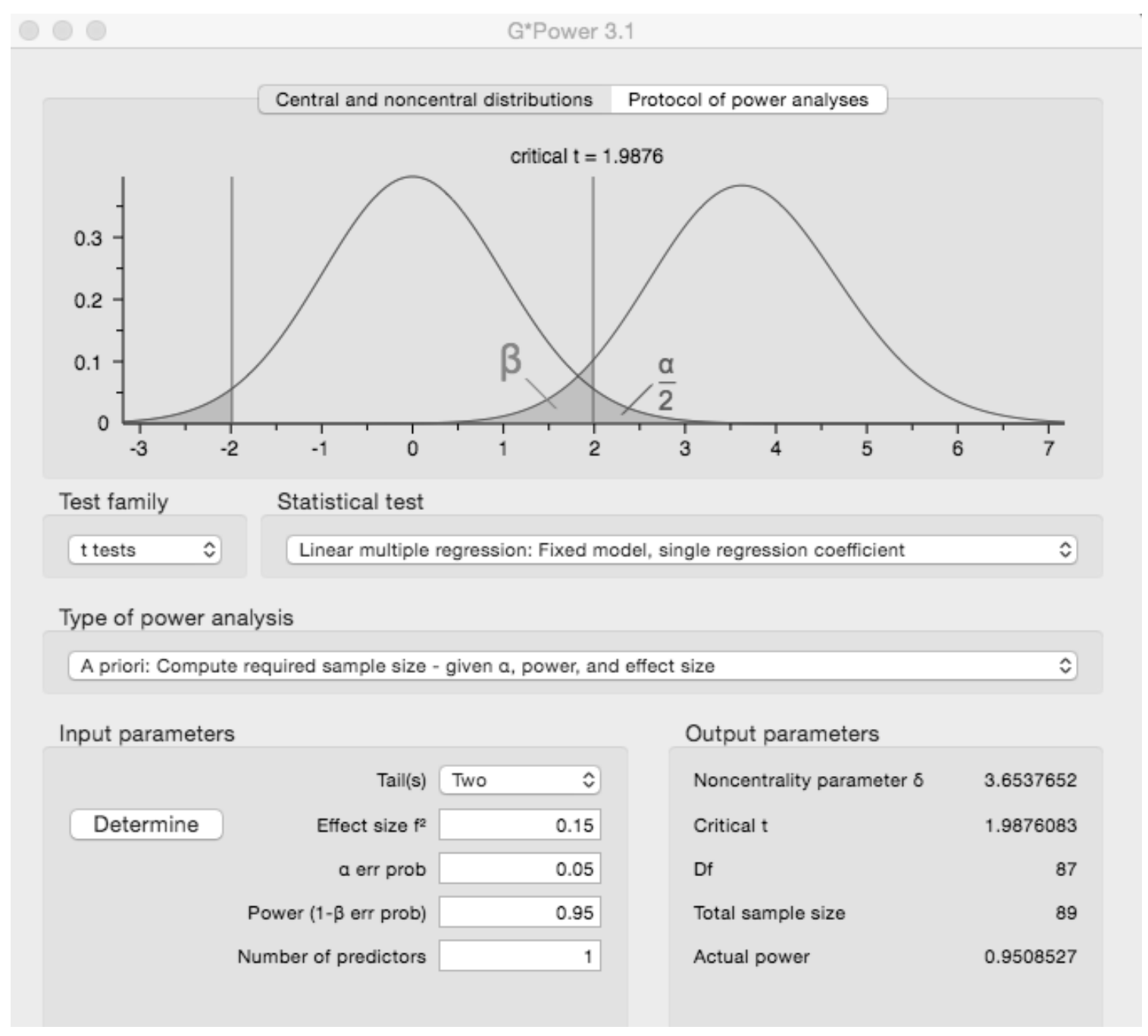

FIGURE 2 G-Power analysis configuration.

In this study, minimum samples were determined by G-power software ${ }^{26}$. The G-Power analysis configuration is shown in Figure 2. The researchers use a partial test (T-test) with a two-tailed test. A two-tailed test is used, for we do not know the path coefficient sign, so the two-tailed is preferred than one-tailed ${ }^{[27}$. The effect size threshold is 0,15 . It means that f2 has moderate value when more than 0,15 . The confidence interval is 0,05 . The hypothesis $\mathrm{H} 0$ will be accepted while T-statistics more than 1,98 or P-value less than 0,025 or P-value more than 0,975 (this happened because this study uses two-tailed) ${ }^{[28]}$. H1 will be accepted when the result is the opposite. The minimum sample size of this study base on the G-Power analysis is 89 respondents.

The questionnaires are made using Google Form. It is spread out by researchers on social media like WhatsApp, Facebook, and Instagram. Verification of questionnaire results and hypothesis testing in this study using the PLS-SEM method and smartPLS software. According to Geladi et al. 29], PLS is a multivariate statistical method that can simultaneously handle many response variables and explanatory variables. PLS is a powerful and robust analysis method because it can be applied to all data scales, does not require many assumptions, and the sample size does not have to be large.

The PLS method has two parts analysis, namely analysis of measurements / inner model and structural/outer models. The structural analysis describes the verification of the research instrument. Research verification is divided into two parts, namely, validity test and reliability test. Validity test on smartPLS is generated with the value of outer loading, Average Variance Extracted (AVE), and Discriminant Validity. The outer loading value illustrates the magnitude of the correlation between each measurement indicator and its construct. The outer loading value must be greater than 0.7. Convergent validity checks are carried out 


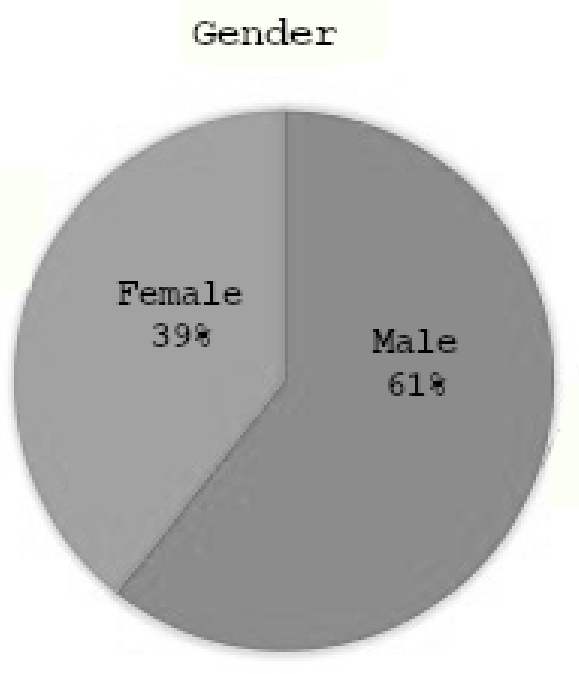

FIGURE 3 Demography of gender.

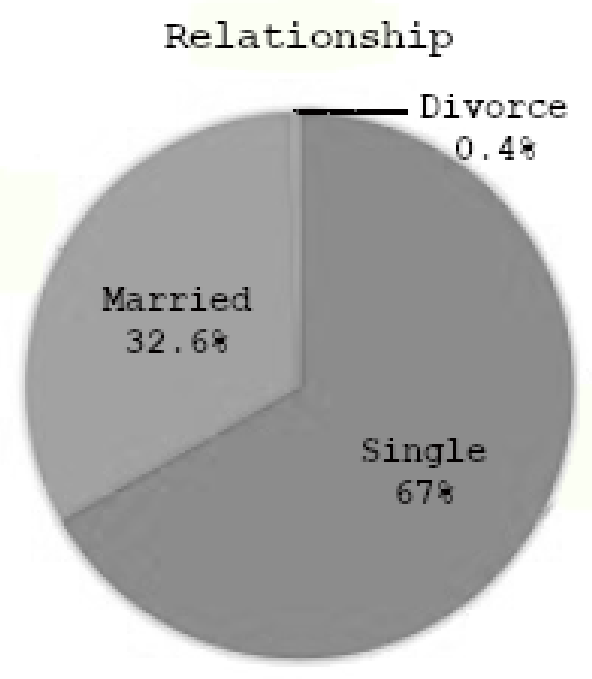

FIGURE 4 Demography of relationship.

through the value of Average Variance Extracted (AVE). The AVE value describes the variance or diversity of manifest variables that can be owned by latent variables. The greater the variance or diversity of manifest variables in latent constructs, the greater the representation of the manifest variable on the latent construct and the AVE that must be greater than 0.5.

Discriminant validity describes the extent to which constructs differ from other constructs empirically or, in other words, constructs measure what they want to measure 29. 30]. Cronbach alpha values and composite reliability generate internal consistency reliability checks. Cronbach alpha and composite reliability the value must be greater than 0.7 . Cronbach alpha is used as a lower limit in the measurement of contracted reliability. Composite reliability in internal consistency reliability examination means that the research indicators define the research construct in full ${ }^{[31}$ [32].

In measurement analysis/ evaluation of inner models, the relationship between the model and latent variables is formulated. In this analysis, the research hypothesis will be tested after the research instrument is declared valid and reliable. The final stage of the research is carried out using structural analysis. The structural analysis value is the value of determination coefficient (R2), path coefficient, and variable effects (f2). Hypothesis testing is carried out at the inner model evaluation stage. This study uses two-tailed tests with a confident interval of 5\%. This means that the hypothesis $\mathrm{H} 0$ is accepted and $\mathrm{H} 1$ is rejected if it has a T-statistic value of more than 1.98 and a P-value value of more than 0.025 or P-value more than 0.975 and vice versa.

\section{3 | RESULTS AND DISCUSSION}

\section{1 | STP Capacity}

In this study, the population is Bukalapak's consumers. This research got respondents of the Bukalapak consumers obtained 210 respondents (more than minimum samples determined by G-Power software). The respondents are the samples which are used to measure the impact from intention consumer to use Bukalapak. In this part, the demography of research data will be discussed.

Figure 3 shows the demographics of the respondent's gender from Bukalapak consumers. The comparison of the number of male and female respondents is $61 \%$ compared to $31 \%$. This result shows a phenomenon that man defeat woman as man dominates Bukalapak's buyer and shopping activity.

The demography of the relationship is shown in Figure 4. The number of unmarried respondents was 141 respondents; the number of married respondents was 69 , and one divorced. 


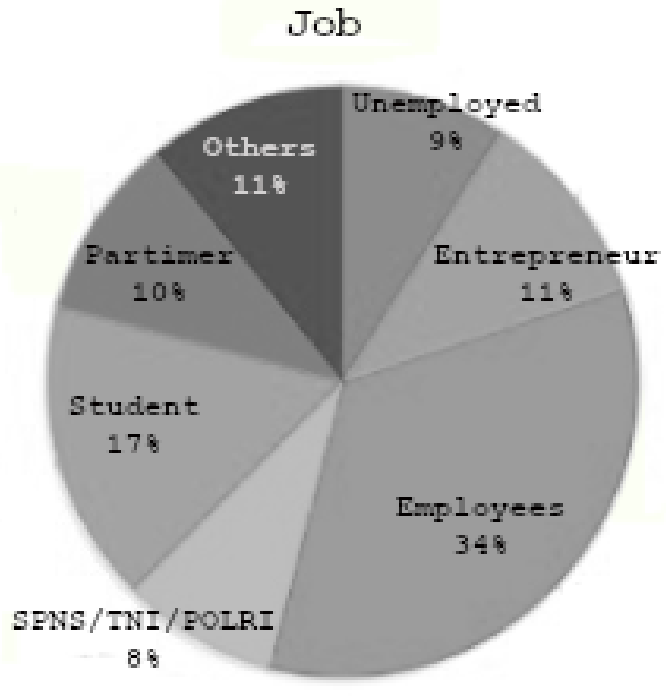

FIGURE 5 Demography of jobs.

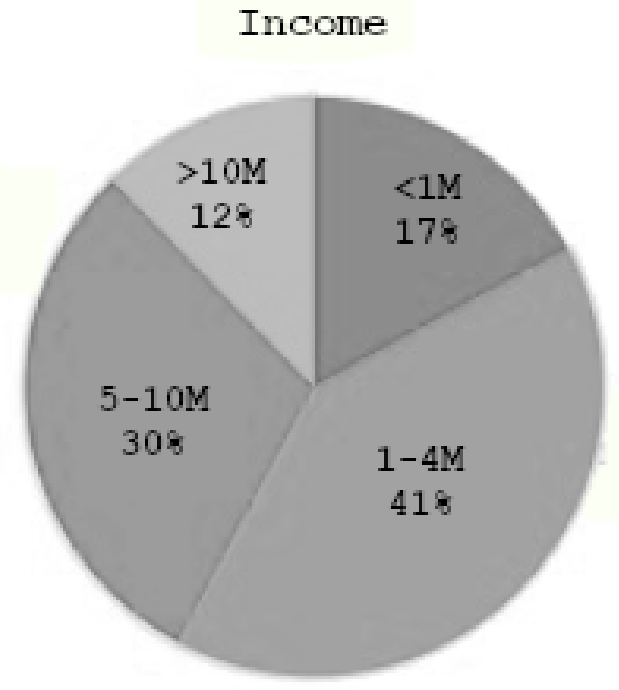

FIGURE 6 Demography of income.

The work of the Bukalapak respondents obtained in this study is quite varied and shown in Figure 5. Respondents who worked as employees were in the first position, with 72 respondents (51\%). Respondents with students' status were 35 respondents (17\%), followed by self-employed respondents, and respondents who had jobs outside the list were $11 \%$ or 23 respondents. One of the jobs outside the list provided in this study were wives who did not work and relied on their husbands' income and were actively shopping at Bukalapak. Respondents who worked as casual workers were $10 \%$ or 21 respondents, and respondents who worked as civil servants/ military/ police were $8 \%$ or 18 respondents. This demography shows that workers who paid every month have money to dominate the respondent. This phenomenon gives information that monthly income influences consumer demographics.

Figure 6 shows the demography of respondent's income. Bukalapak respondents had the most income of 1 million to 4 million rupiahs, with 86 respondents $(41 \%)$. The second place is respondents whose income between 5 million up to 10 million rupiahs of $30 \%$ or 63 respondents. Thirty-six respondents (17\%) had income below 1 million rupiahs, and $12 \%$ or 26 respondents had income above 10 million. Most Bukalapak's consumers are Indonesian middle class, which has an average income similar to Indonesian average income ${ }^{33]}$.

The demography of age is shown in Figure 7. Respondents in the age range of 24 to 30 years have the largest number, with 109 respondents (52\%), in the second place with 62 respondents (29\%) aged 17 to 23 years. This study only received one respondent under 17, while respondents aged over 36 years were 26 respondents (12\%), and respondents aged between 31 and 35 years were 13 respondents $(6 \%)$. Most of Bukalapak's consumers are Millenials. This generation is capable of using and get the facility to buy on Bukalapak.

The verification of the questionnaire results is shown in Tables 2 until 5. Table 2 is the result of variable validation tests involving indicators on each variable. All indicator values in the behavior intention variable and user behavior have a value of more than 0.7. This means that all the indicators are valid. Reliable in table 2, it can be seen that the degree of the purpose of using market place has more influence than the degree of the intention of consumers in using the market place.

In the next stage, the results of the variable diversity test are shown in table 3. The Average Variance Extracted value in table 3 shows that the latent variable intention behavior and use behavior are more than 0.5 . Behavior intention has a value of 0.83 and means that the intention behavior variable's indicator is good enough to represent its latent variables. In the user behavior, the variable has a value of 1 because it only has one indicator. 


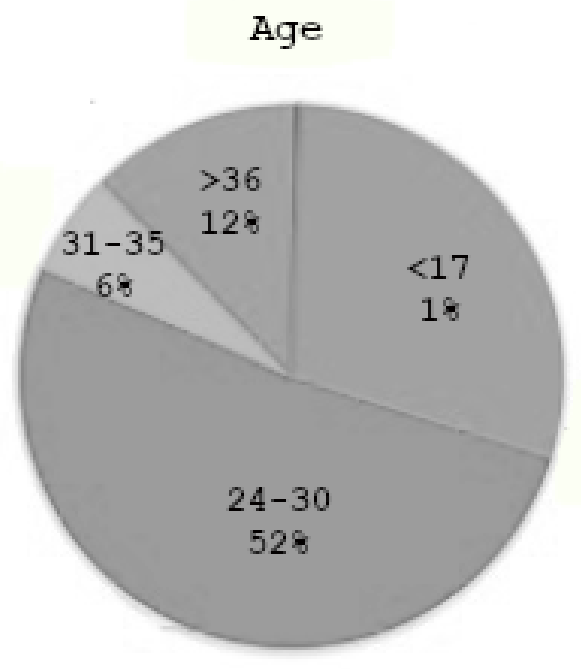

FIGURE 7 Demography of age.

TABLE 2 Outer loading validation.

\begin{tabular}{llll}
\hline $\begin{array}{l}\text { Outer } \\
\text { Loading }\end{array}$ & $\begin{array}{l}\text { Behavioral } \\
\text { Intention }\end{array}$ & $\begin{array}{l}\text { Use } \\
\text { Behaviour }\end{array}$ & Justification \\
\hline BI.1 & 0.88553263 & - & Valid \\
BI.2 & 0.94623729 & - & Valid \\
UB.1 & - & 1 & Valid \\
\hline
\end{tabular}

TABLE 3 AVE validation.

\begin{tabular}{lll}
\hline Variable & AVE & Justification \\
\hline Behavioral Intention & 0.83976652 & Valid \\
Use Behaviour & 1 & Valid \\
\hline
\end{tabular}

Examining construct validity with discriminant validity values in table 4 shows that each indicator value for its latent variables is more significant than other latent variables. This indicates that there are no interchangeable indicators or misplaced indicators used to explain latent variables.

TABLE 4 Discriminant reliability.

\begin{tabular}{lll}
\hline Variable & $\begin{array}{l}\text { Behavioral } \\
\text { Intention }\end{array}$ & $\begin{array}{l}\text { Use } \\
\text { Behaviour }\end{array}$ \\
\hline BI.1 & 0.88553263 & 0.25273612 \\
BI.2 & 0.94623729 & 0.36298335 \\
UB.1 & 0.34486386 & 1 \\
\hline
\end{tabular}

TABLE 5 Internal consistency reliability.

\begin{tabular}{llll}
\hline Variable & $\begin{array}{l}\text { Cronbach's } \\
\text { Alpha }\end{array}$ & $\begin{array}{l}\text { Composite } \\
\text { Reliability }\end{array}$ & Justification \\
\hline Behavioral Intention & 0.81491711 & 0.91281823 & Reliable \\
Use Behaviour & 1 & 1 & Reliable \\
\hline
\end{tabular}

The internal consistency reliability check-in Table 5 shows that all latent variables in measurements with Cronbach alpha and composite reliability are more than 0.7 . The value of composite reliability on the latent behavior intention variable is 0.9 , which means that the latent variable's indicator is good enough to define the latent variable.

The coefficient determination is shown in Table 6. It will define the model fit. The research model formed in this study to measure user behavior of Bukalapak consumers only represents $12 \%$ in explaining the factors that influence consumers to continue shopping at Bukalapak while $88 \%$ of other factors are outside of this study.

This is also reinforced by the value of $\mathrm{f} 2$ of 0.023 , which means that the model made is not acceptable to describe the factors that influence consumers' attitudes to continue shopping at Bukalapak.

The hypothesis examination result is shown in Table 8 . We also identified the positive influence of the latent behavioral intention variable in influencing the use of behaviors of Bukalapak consumers. This positive influence is followed by the effect of a 
TABLE 6 Coefficient determination of Use Behavior.

\begin{tabular}{ll}
\hline Parameter & Value \\
\hline R2 & 0.127368352396752 \\
R2 Adjusted & 0.12317300793712 \\
\hline
\end{tabular}

TABLE 7 Variable effect.

\begin{tabular}{lll}
\hline $\begin{array}{l}\text { Variable } \\
\text { Connection }\end{array}$ & $f^{2}$ & Justification \\
\hline $\begin{array}{l}\text { Behavioural } \\
\text { Intention } \rightarrow \text { Use } \\
\text { Behaviour }\end{array}$ & 0.023 & Less effect \\
\hline
\end{tabular}

TABLE 8 Significance of variable.

\begin{tabular}{lllll}
\hline Variable Connection & Path coefficient & T-statistic & P-value & Justification \\
\hline Behavioural Intention $\rightarrow$ Use Behaviour & 0.34486386 & 5.60836574 & 0.0000000338514 & Significant \\
\hline
\end{tabular}

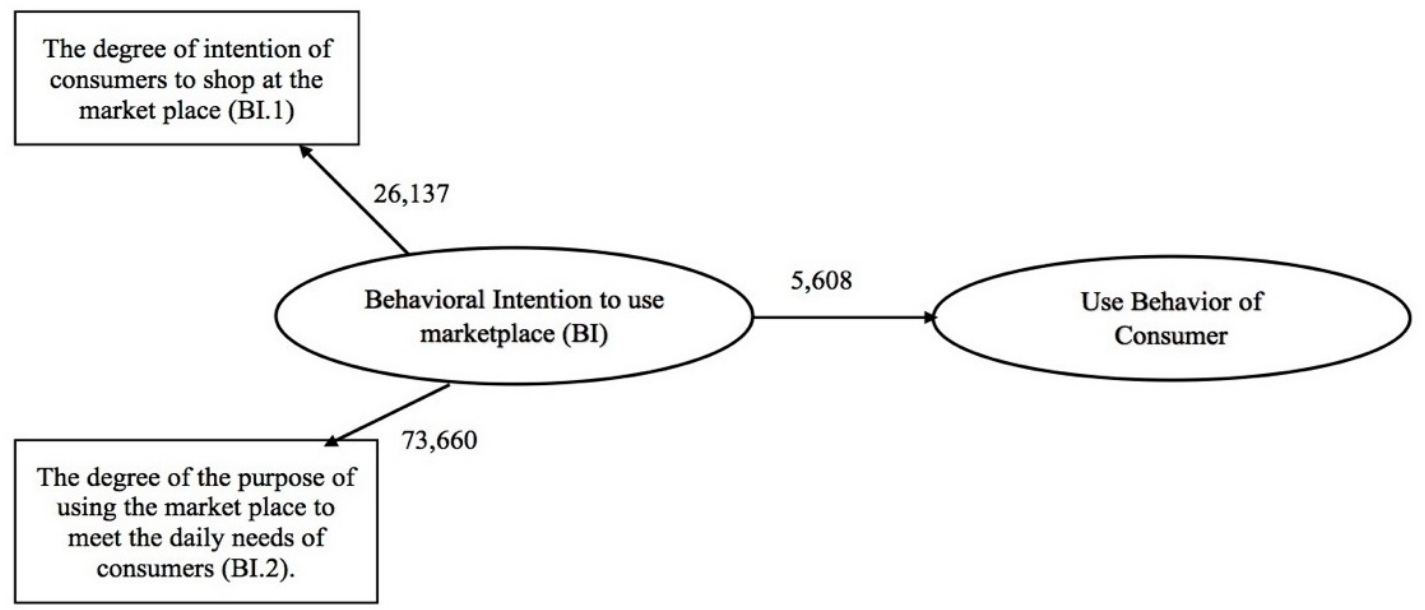

FIGURE 8 Path coefficient result from each indicator.

significant behavioral intention to use behavior. The value can see this of T-statistics, which is more than 1.98, and the P-value is less than 0.025 . Therefore the hypothesis $\mathrm{H} 0$ is accepted, and $\mathrm{H} 1$ is rejected. The result shows that behavioral intention has significant value in influencing the usage behavior of Bukalapak's consumer.

Figure 8 shows that the dominant indicator is the second indicator, which has value 73.660 and 26.137 for the first indicator. The second indicator shows the degree of the purpose of using the market place to meet the daily needs of consumers. The result indicates that Bukalapak's consumers use (shop on) Bukalapak for fulfilling their daily needs than use Bukalapak continuously. The phenomena occur because most respondents of this research are millennials, and they have opportunities behavior when buying an item ${ }^{[23}$. Millennials also have the experience to use new technology like the electronic market place ${ }^{34}$. Bukalapak's consumer income equal to the income of Indonesian makes it selective in choosing the goods. Stockdale and Standing 35 examined the prospective market place on small to medium firms (SME). They found that many firms used the market place to injected the market quickly and decreased marketing costs. This phenomenon follows the vagueness of Business to Consumers' core business and Consumer to Consumer core business. A market place sells their product in another market place.

\section{4 | CONCLUSION}

Behavior intention has a positive and significant influence on the use of behavior of Bukalapak consumers. Positive and significant effects indicate that Bukalapak consumers still intend to shop at Bukalapak. This positive and significant influence can be interpreted that the existence of a market place in Indonesia, especially Bukalapak, is still in demand by Indonesia's people. These are known based on the behavior intention variable, which has a formation of the degree of consumer intention in using 
the market place. It is more significant in establishing the use behavior variable than the purpose of using the market place to meet consumers' daily needs. This means there is a need for consumers to shop at Bukalapak.

Bukalapak can have its product and sell it not only on Bukalapak apps but also in another market place without changing its brand. This study shows that the majority of Indonesian people are the millennial generation who are technology literate. The generation is mostly college graduates and at least high school. This socially constitutes a significant middle class in society. Reported to bisnis.com ${ }^{36}$ eCommerce Regional Commercial Director JC Chen said that Indonesia, with a large middle class, is an attractive and promising market.

This study focuses on the influence of behavioral intention on user behavior. The development of further research models can develop marketing strategies of Bukalapak by adding variable performance expectancy and social influence

\section{References}

1. Rojko A. Industry 4.0 Concept: Background and Overview. International Journal of Interactive Mobile Technologies (iJIM) 2017;11(5):77-90.

2. Bettiol M, Capestro M, Maria ED. Industry 4.0: The Stategic Role of Marketing. Proceedings of the XIV Convegno Annuale SIM 2017;p. 26-27. https://www.researchgate.net/publication/ $320922780\left\{_{-}\right\}$INDUSTRY $\left\{_{-}\right\} 40\left\{_{-}\right\}$THE $\left\{_{-}\right\}$STRATEGIC $\left\{_{-}\right\}$ROLE $\left\{_{-}\right\} O F\left\{_{-}\right\}$MARKETING.

3. Wigand RT. Electronic Commerce: Definition, Theory, and Context. The information Society 1997;13(1):1-16.

4. Lin HH, Wang YS. Predicting Consumer Intention to Ise Mobile Commerce in Taiwan. In: 4th Annual International Conference on Mobile Business, ICMB 2005 IEEE; 2005. p. 406-412.

5. Luarn P, Lin HH. Toward an Understanding of The Behavioral Intention to Use Mobile Banking. Computers in Human Behavior 2005 Nov;21(6):873-891.

6. Vassileva B. Marketing 4.0: How Technologies Transform Marketing Organization. Óbuda University e-Bulletin 2017;7(1):47-56. https://www.researchgate.net/publication/ $317077452\left\{_{-}\right\}$Marketing $\left\{_{-}\right\} 40\left\{_{-}\right\}$How $\left\{_{-}\right\}$Technologies $\left\{_{-}\right\}$Transform $\left\{_{-}\right\}$Marketing \{_\}Organization

7. Andreasen AR. Marketing Social Marketing in the Social Change Marketplace. Journal of Public Policy \& Marketing 2002 Apr;21(1):3-13. http://journals.sagepub.com/doi/10.1509/jppm.21.1.3.17602.

8. Bhamra T, Lilley D, Tang T. Design for Sustainable Behaviour: Using Products to Change Consumer Behaviour. The Design Journal 2011 Dec;14(4):427-445.

9. Turhan G, Ozbek A. Factors Affecting Consumers' Behavioural Intention Towards Apparel stores: A Test of the Mediating Role of Brand Satisfaction. FIBRES \& textiles in Eastern Europe 2013;97(1):7-13. http://fibtex.lodz.pl/article834.html

10. Dignum F. E-commerce in Production: Some Experiences. Integrated Manufacturing Systems 2002;13(5):283-294.

11. Souiden N, Pons F. Product Recall Crisis Management: The Impact on Manufacturer's Image, Consumer Loyalty and Purchase Intention. Journal of Product and Brand Management 2009 Apr;18(2):106-114.

12. Zarantonello L, Schmitt BH. Using the Brand Experience Scale to Profile Consumers and Predict Consumer Behaviour. Journal of Brand Management 2010 July;17(7):532-540.

13. Dennis C, Merrilees B, Jayawardhena C, Wright LT. E-Consumer Behaviour. European Journal of Marketing 2009 Sep;43(9):1121-1139.

14. Gupta A. E-Commerce: Role of E-commerce in Today's Business. International Journal of Computing and Corporate Research 2014;4(1):1-8. 
15. Shahjee R. The Impact of Electronic Commerce on The Business Organization. Scholarly Research Journal for Interdisciplinary Studies 2016;4(27):3130-3140.

16. Subba Rao S, Truong D, Senecal S, Le TT. How buyers' expected benefits, perceived risks, and e-business readiness influence their e-marketplace usage. Industrial Marketing Management 2007 Nov;36(8):1035-1045.

17. Ok Sj, Shon Jh. The Determinant of Internet Banking Usage Behavior in Korea: A Comparison of Two Theoretical Models. ColleCTeR 2006;.

18. Mustaqim RN, Kusyanti A, Aryadita H. Analisis Faktor-Faktor yang Memengaruhi Niat Penggunaan E-Commerce XYZ Menggunakan Model UTAUT (Unified Theory Acceptance and Use Of Technology). Jurnal Pengembangan Teknologi Informasi dan Ilmu Komputer 2018;2(7):2584-2593. http://j-ptiik.ub.ac.id/index.php/j-ptiik/article/view/1653/608

19. Venkatesh V, Morris MG, Davis GB, Davis FD. User Acceptance of Information Technology: Toward a Unified View. MIS Quarterly 2003;27(3):425-478.

20. T W, J H, W B. Conceptualising Usage in Voter Behaviour for Political Marketing: An Application of Consumer Behaviour. Journal of Political Marketing 2016;15(2-3):254-284.

21. Venkatesh V, Brown SA, Maruping LM, Bala H. Predicting Different Conceptualizations of System Use: The Competing Roles of Behavioral Intention, Facilitating Conditions, and Behavioral Expectation. MIS Quarterly 2008;32(3):483-502.

22. Schwarz A, Chin W. Looking Forward: Toward an Understanding of the Nature and Definition of IT Acceptance. Journal of the Association for Information Systems 2007;8(4):230-243.

23. Rosnidah I, Muna A, Musyaffi AM, Siregar NF. Critical Factor of Mobile Payment Acceptance in Millenial Generation: Study on the UTAUT Model. In: International Symposium on Social Sciences, Education, and Humanities (ISSEH 2018) Atlantis Press; 2019. p. 123-127.

24. Venkatesh V, Zhang X. Unified theory of acceptance and use of technology: U.S. vs. China. Journal of Global Information Technology Management 2010;13(1):5-27.

25. Abdillah W, Hartono J. Partial Least Square (PLS): alternatif Structural Equation Modeling (SEM) dalam Penelitian Bisnis. Yogyakarta: Andi; 2015.

26. Mayr S, Erdfelder E, Buchner A, Faul F. A Short tutorial of GPower. Tutorials in Quantitative Methods for Psychology 2007;3(2):51-59.

27. Kock N. One-Tailed or Two-Tailed P Values in PLS-SEM? International Journal of e-Collaboration (IJeC) 2015;11(2):1-7.

28. Park HM. Hypothesis Testing and Statistical Power of a Test. Test 2010;1(4):4724-4812.

29. Geladi P, Kowalski BR. Partial Least-Squares Regression: A Tutorial. Analytica Chimica Acta 1986 Jan;185:1-17.

30. Hair JF, Ringle CM, Sarstedt M. Partial least squares structural equation modeling (PLS-SEM). Journal of Marketing Theory and Practice 2011;19(2):139-152.

31. Hair JF, Black WC, Babin BJ, Anderson RE. Multivariate Data Analysis with Readings. 4 ed. Upper Saddle River, NJ, USA: Prentice Hall; 1995.

32. Bollen KA. Evaluating Effect Composite and Causal Indicators in Structural Equation Models. MIS Quarterly 2011 June;35(2):359-372. https://www.jstor.org/stable/23044047.

33. Joseph F H, Hult GTM, Ringle C, Sarstedt M. Partial Least Squares Structural Equation Modeling. 2 ed. Los Angeles: Springer International Publishing; 2017.

34. Arenas Gaitan J, Peral BP, Jeronimo MR. Elderly and Internet Banking: An Application of UTAUT2. Journal of Internet Banking and Commerce 2015;20(1):1-23. 
35. Stockdale R, Standing C. Benefits and Barriers of Electronic Marketplace Participation: An SME Perspective. Journal of Enterprise Information Management 2004;17(4):301-311.

36. Herlinda WD. Kompetisi Marketplace: Bertarung Melawan RaksasaN. Bisniscom 2018:https://ekonomi.bisnis.com/read/ 20180516/12/795788/-kompetisi-marketplace-bertarung-melawan-raksasa

How to cite this article: Giandi O., Irawan I., Ambarwati R., (2020), Determinants of Behavior Intention and Use Behavior among Bukalapak's Consumers, IPTEK The Journal of Technology and Science, 31(2):158-168. 